\title{
Temporal Changes in Total Serum Immunoglobulin E Levels in East German Children and the Effect of Potential Predictors
}

\author{
Katrin Flohrs ${ }^{\mathrm{a}}$ Irene Brüske ${ }^{\mathrm{a}}$ Elisabeth Thiering ${ }^{\mathrm{a}}$ Peter Rzehak $^{\mathrm{a}, \mathrm{b}}$ \\ H.-Erich Wichmann ${ }^{a}$ b Joachim Heinrich ${ }^{a}$ \\ ${ }^{a}$ Helmholtz Zentrum München, German Research Center for Environmental Health, Institute of Epidemiology, \\ Neuherberg, and ${ }^{\mathrm{b}}$ Ludwig Maximilians University, Institute of Medical Informatics, Biometry and Epidemiology, \\ Munich, Germany
}

\section{Key Words}

Allergy $\cdot$ Children $\cdot$ Helminth infection $\cdot$ Immunoglobulin $\mathrm{E}$, total $\cdot$ Trend

\begin{abstract}
Background: Elevated total serum immunoglobulin $\mathrm{E}(\lg \mathrm{E})$ levels are a prominent feature of allergic and parasitic diseases. An epidemiologic study was conducted in East German children to describe trends in the development of total serum IgE levels and analyze the impact of potential determinants. Methods: The study consisted of three cross-sectional surveys in 1992-1993, 1995-1996 and 1998-1999 and was conducted in three areas of the former German Democratic Republic. In total, 8,051 questionnaires were completed by the parents of children aged 5-14 years, supplying information on allergic symptoms and potential risk factors. A total of 5,918 measurements of total serum IgE and specific $\operatorname{lgE}$ to 5 common aeroallergens were available from 4,353 schoolchildren. Generalized estimating equations were applied to data from all children and stratified for atopic and nonatopic children to identify trends and estimate the effect of potential determinants on total IgE. Results: Total serum IgE levels decreased significantly with a linear trend in East German schoolchildren between 1992 and 1999, the effect being stronger in nonatopic children. The following factors
\end{abstract}

were associated with lower total serum IgE levels: female gender, living in a household with fewer than 4 people, no history of helminth infestation, younger age group (5-7 years), no parental allergy and high socioeconomic status. No association was seen for 'smoking at home' and close contact to pets. Conclusion: Total serum IgE declined parallel to helminth infestation; however, the latter explained the decrease only in part. Furthermore, total IgE developed in an opposite direction to specific $\lg \mathrm{E}$, indicating that it has determinants other than allergic sensitization.

Copyright $\odot 2011$ S. Karger AG, Basel

\section{Introduction}

In recent decades, the prevalence of allergic diseases has increased worldwide. Atopy-related diseases are the most common chronic disorders in children in Western societies. Allergic sensitization and atopic symptoms are associated with elevated levels of total serum immunoglobulin E (IgE), and increased IgE levels are a risk factor for the development of asthma. IgE is influenced by various environmental factors, including viral, parasitic and bacterial infection [1], indoor air pollution [2], genetic background [3, 4], diet [5], smoking habits [6] and other determinants related to a 'Western lifestyle' [7]. Although

\section{KARGER}

Fax +4161306 1234 E-Mail karger@karger.ch www.karger.com

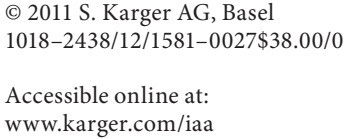

Correspondence to: Dr. Joachim Heinrich

Helmholtz Zentrum München, Institute of Epidemiology

Ingolstaedter Landstrasse 1

DE-85764 Neuherberg (Germany)

Tel. +49893187 4150, E-Mail joachim.heinrich@helmholtz-muenchen.de 


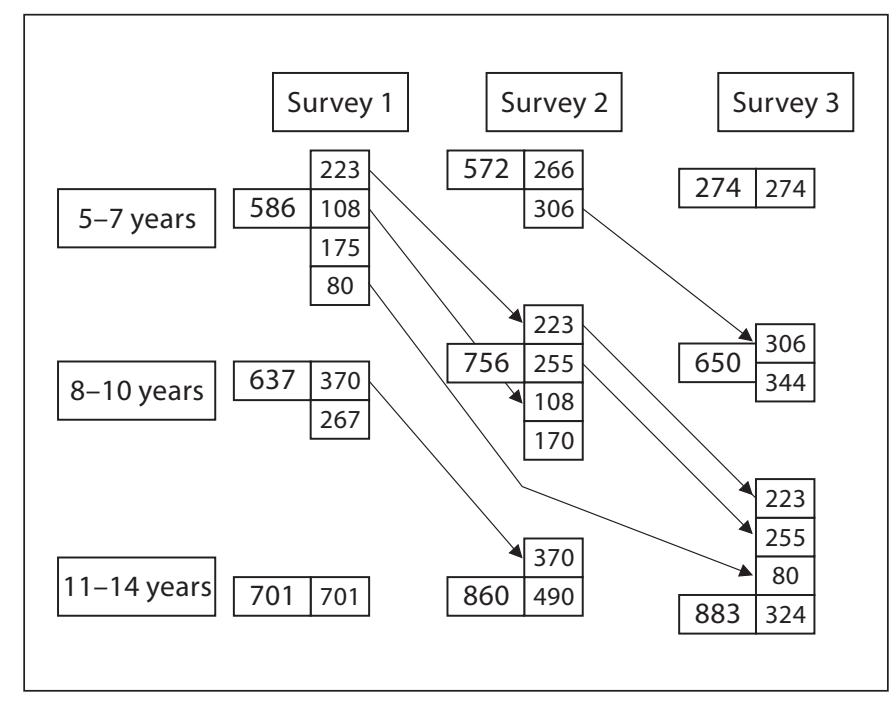

Fig. 1. Three consecutive regional cross-sectional surveys were conducted in 1992-1993, 1995-1996 and 1998-1999. Three areas of East Germany (Zerbst, Hettstedt and Bitterfeld County) were included in each survey.

there is strong evidence for a genetic predisposition to atopic diseases $[8,9]$, the rapid changes and the huge variation across populations favor environmental explanations [10].

After the German reunification in 1989, several studies conducted in the early 1990s showed a higher prevalence of allergic diseases such as asthma and hay fever in adults and children [11-13] in West Germany (former Federal Republic of Germany) compared to East Germany (former German Democratic Republic). However, total serum IgE levels were found to be higher in East German individuals [12].

People in East Germany quickly adopted a 'Western lifestyle' after German reunification, which included better house insulation and tighter windows with a subsequent increase in dampness and molds [14], fewer homes heated with coal or wood [14], more cars, exotic food [15], fewer infectious diseases, including helminth infestations $[16,17]$, and more pet-keeping. It was presumed that the prevalence of allergic diseases would rise and approach levels in West Germany, and this trend has actually been observed in several studies in recent years $[12$, 18-20].

Several known or supposed determinants for total $\operatorname{IgE}$ $[1,17,21]$ could be considered driving forces behind the temporal changes in total IgE levels in East German children. We decided to evaluate the impact of gender, age, residency, parental education, household size, helminth infection, parental allergy, smoking at home and contact to cats/dogs on total IgE in children.

The objective of this study was to describe trends in total serum IgE levels in East German children and to identify environmental allergic risk factors for high IgE levels in this population.

\section{Methods}

\section{Subjects and Setting}

This study consisted of three consecutive regional cross-sectional surveys conducted in 1992-1993, 1995-1996 and 19981999 [for details, see ref. 22]. Each survey was conducted in three areas of East Germany (Zerbst, Hettstedt and Bitterfeld County) with differing air pollution levels (fig. 1). In each survey, all school entrants (age range 5-7 years), third graders (age range 8-10 years) and sixth graders (age range 11-14 years) who were residents of Zerbst and Hettstedt, and a subgroup of children from Bitterfeld County were invited to participate in this study. All day care centers and schools in Zerbst and Hettstedt counties were contacted. In the larger area of Bitterfeld County, schools and day care centers were randomly selected to represent all children in these age groups. Some of the children were reexamined in the subsequent survey(s). Bitterfeld and Hettstedt counties were heavily polluted in the past by emissions from chemical plants, smelters and power plants burning brown coal with high sulfur content. Zerbst served as a control region with background pollution. The University of Rostock Ethics Committee approved the study protocol. Informed consent was obtained from the parents of all participating children. The data collection and methods have already been described in detail $[22,23]$.

\section{Questionnaire}

Teachers distributed questionnaires to the childrens' parents and collected them a week later. The questionnaire was developed by using questions previously validated in several international studies [24] and contained 78 items adapted to address East German living conditions. It covered questions concerning physicians' diagnoses and typical symptoms of respiratory and allergic disorders, demographic characteristics, parental school education as a proxy parameter for socioeconomic status and possible pathogenic factors. Family history of atopic diseases was considered positive if at least one of the following conditions was present in the mother, father or both: asthma, hay fever, eczema or other forms of allergy. The question regarding whether the child had ever had a helminth infestation and if so at what age was only present in the second and third surveys. For children who participated in the first and second surveys, answers given in the second survey could be used to supplement the 'helminth infestation status'.

\section{Total and Specific IgE}

Serum samples were drawn from more than $80 \%$ of the children and were immediately frozen and stored at $-80^{\circ} \mathrm{C}$ until the end of the second survey, when they were all analyzed together. The serum samples from the third survey were also stored and analyzed together. Total serum IgE and specific IgE were deter- 
mined by an immunoassay and RAST technique, respectively (Pharmacia Diagnostics AB, Uppsala, Sweden). Specific IgE measurements covered grass g6, dust mite (Dermatophagoides pteronyssinus) $\mathrm{d} 1$, cat e1, Cladosporium $\mathrm{m} 2$ and birch $\mathrm{t} 3$ antigens. Individuals with specific IgE levels greater than or equal to $0.35 \mathrm{kU} / \mathrm{l}$ were considered to be sensitized and classified as atopic. Total IgE was determined with a detection limit of $2 \mathrm{kU} / \mathrm{l}$ and an upper limit of 2,000 kU/l. As there was no upper limit for total IgE here, all values greater than $2,000 \mathrm{kU} / \mathrm{l}$ were set to $2,000 \mathrm{kU} / 1$ to make them comparable with those from the first and second survey. All measurements were conducted by a single laboratory (Pharmacia, Freiburg, Germany).

\section{Statistical Analysis}

Total serum IgE values were log transformed due to the skewed distribution. The association between log-transformed total IgE and potential determinants, including parental education, number of persons living in the household, helminth infestation, parental allergy, smoking at home, contact to cats or dogs and sensitization to at least one specific $\operatorname{IgE}(>0.35 \mathrm{kU} / \mathrm{l})$, was calculated using generalized estimating equations with a Gaussian response function. The correlation between repeated measurements in the same individual was assumed to be larger between two successive surveys $(\rho=0.8)$ and smaller between the first and last survey $(\rho=0.5)$. Results are presented as estimated effects of the potential determinants on the log-transformed total IgE level with confidence intervals and $\mathrm{p}$ values. Additionally, mean ratios (MRs) are provided to express percentage differences between groups.

Confounders, including age group, sex and study region, were adjusted in each model. All analyses were performed using R version 2.9.0.

\section{Results}

\section{Study Population}

In total, 8,051 of 9,630 distributed questionnaires were completed by the childrens' parents. The response rates varied between 68.6 and $92.1 \%$ between study areas and surveys (table 1). In all, 6,461 of these responses contained measurements of total serum IgE. A total of 3,155 children participated in one survey, 1,263 in two surveys and 260 in all three consecutive surveys. For this study, we analyzed 5,918 data derived from 4,353 schoolchildren.

Children from the first survey were comparable with those participating in the second and third surveys with regard to sex and parental education. However, due to a general decrease in birth rates in East Germany after German reunification in 1990, the children in the later surveys were slightly older compared to the children from the first survey (average age in the second and third surveys was 9.1 and 9.7 years, respectively, vs. 8.9 years in the first survey).

Temporal Changes in Total Serum IgE

\section{Temporal Changes in Total Serum IgE Levels and Potential Predictors}

The crude geometric means of total serum IgE levels were $66.3 \mathrm{kU} / \mathrm{l}$ in the first, $60.9 \mathrm{kU} / \mathrm{l}$ in the second and 57.9 $\mathrm{kU} / \mathrm{l}$ in the third survey (table 1). When adjusted for sex, age group and study region, IgE decreased linearly between the first and the third survey $(p<0.001)$. This overall trend was due to the trend in the number of nonatopic children.

The percentage of children with at least one parent having one or more allergic diseases (asthma, hay fever, eczema or other forms of allergy) increased slightly from $27.0 \%$ in the first survey to $33.3 \%$ in the third (table 1). The proportion of children living in households with more than 4 persons rose from $17.5 \%$ in survey 1 to $21.0 \%$ in survey 3 . In the first survey, $46.6 \%$ of the study population reported close contact to cats and/or dogs, compared to $61.4 \%$ in the third survey. The percentage of children with a positive RAST ranged between 29.5 and $32.2 \%$ across the three surveys (table 1).

Although the lifetime prevalence of helminth infestations in children increases with age - and the average age rose during the study - the percentage of children with a history of helminth infestation dropped between the second and the third survey. As the information on helminth infection missing in the first survey could only be estimated for those children also participating in the second survey, these data were absent in survey 1 for the third age group (individuals of the third age group were not reconsulted in subsequent surveys). These children from the first survey had higher crude prevalences than other children in their age groups in the following surveys (data not shown). Helminth infection was more frequent in girls than boys (14.9 vs. $11.7 \%$ for the three surveys together).

\section{The Role of Potential Predictors}

Generalized estimating equations for repeated measurements estimated the effect of the potential determinants shown in table 2 on log-transformed total serum IgE for all children and stratified for atopic and nonatopic children. Atopic children had higher levels of total serum IgE (intercept 4.55) than children in the overall group (intercept 3.87) and nonatopic children (intercept 3.72). Boys had significantly $(\mathrm{p}<0.001)$ higher total serum IgE levels than girls (MR 1.40). The gender difference in total serum IgE was smaller when stratifying for the group of atopic (MR 1.32) and nonatopic (MR 1.12) children. IgE levels were generally higher in the age groups 8-10 years and 11-14 years as compared to the age group 5-7 years, even though differences were smaller in 
Table 1. Characteristics of the study populations of surveys 1 (1992-1993), 2 (1995-1996) and 3 (1998-1999)

\begin{tabular}{|c|c|c|c|}
\hline & $\begin{array}{l}\text { Survey } 1 \\
(\mathrm{n}=1,924)\end{array}$ & $\begin{array}{l}\text { Survey } 2 \\
(\mathrm{n}=2,188)\end{array}$ & $\begin{array}{l}\text { Survey } 3 \\
(\mathrm{n}=1,806)\end{array}$ \\
\hline Median total serum IgE, kU/l & 51.9 & 58.8 & 62.2 \\
\hline $\log$ total serum IgE, $\mathrm{kU} / \mathrm{l}$ & $4.2 \pm 1.4$ & $4.1 \pm 1.5$ & $4.1 \pm 1.4$ \\
\hline \multicolumn{4}{|l|}{ Study subjects } \\
\hline Zerbst & $677(35.2)$ & $603(27.6)$ & $520(28.8)$ \\
\hline Bitterfeld & $606(31.5)$ & $966(44.1)$ & $742(41.1)$ \\
\hline Hettstedt & $641(33.3)$ & $619(28.3)$ & $544(30.1)$ \\
\hline \multicolumn{4}{|l|}{ Demographic characteristics } \\
\hline Age, years & $8.9 \pm 2.6$ & $9.1 \pm 2.6$ & $9.7 \pm 2.3$ \\
\hline \multicolumn{4}{|l|}{ Age groups } \\
\hline $5-7$ years & $586(30.5)$ & $572(26.1)$ & $274(15.2)$ \\
\hline $8-10$ years & $637(33.1)$ & $756(34.6)$ & $650(36.0)$ \\
\hline $11-14$ years & $701(36.4)$ & $860(39.3)$ & $882(48.8)$ \\
\hline Males & $972(48.0)$ & $1,163(53.2)$ & $957(53.0)$ \\
\hline \multicolumn{4}{|l|}{ Parental education } \\
\hline$<10$ years of school education & $129(6.7)$ & $172(7.9)$ & $130(7.2)$ \\
\hline 10 years of school education & $943(49.0)$ & $1,104(50.5)$ & $915(50.7)$ \\
\hline 12 years of school education & $852(44.3)$ & $912(41.7)$ & $761(42.1)$ \\
\hline \multicolumn{4}{|l|}{ Potential determinants } \\
\hline Parental atopy & $519(30.0)$ & $674(29.6)$ & $601(33.3)$ \\
\hline$>4$ persons per dwelling & $337(17.5)$ & $408(18.6)$ & $380(21.0)$ \\
\hline History of helminth infestation & $137(7.1)$ & $398(18.2)$ & $284(15.7)$ \\
\hline No history of helminth infestation & $754(39.2)$ & $1,777(81.2)$ & $1,509(83.6)$ \\
\hline Unknown history of helminth infestation & $1,033(53.7)$ & $13(0.6)$ & $13(0.7)$ \\
\hline Contact to cats and/or dogs & $896(46.6)$ & $1,142(52.2)$ & $1,109(61.4)$ \\
\hline ETS exposure & $897(46.6)$ & $963(44.0)$ & $788(43.6)$ \\
\hline Allergic sensitization of the child ${ }^{1}$ & $614(31.9)$ & $645(29.5)$ & $581(32.2)$ \\
\hline
\end{tabular}

nonatopic children. Children living in households of more than 4 persons had significantly higher IgE levels than children living in households with up to 4 (MR 1.23; $\mathrm{p}<0.001)$. In the stratified analysis according to atopic disease status, the effect was stronger for the group of nonatopic children (MR 1.32) compared to the group of atopic children (MR 1.26). Children with a history of helminth infestation had higher IgE levels than those without (MR 1.13; $\mathrm{p}<0.05)$, but this effect was most pronounced in nonatopic children (MR 1.22; $\mathrm{p}<0.001$ ), while it was lower and not significant in the group of atopic children. An opposite effect was seen for parental education; children of parents with school education of 10-12 years or more than 12 years had lower total IgE levels compared to those with parental school education of less than 10 years (MR 0.86 and 0.85 , respectively; $\mathrm{p}<$ 0.05 ), and this effect was strongest in nonatopic children
(MR 0.82 and 0.77 , respectively; $\mathrm{p}<0.05$ ). Parental allergy was associated with significantly higher values of $\operatorname{IgE}(\mathrm{MR} 1.11 ; \mathrm{p}<0.01)$, but this lost its impact after stratification for sensitization of the children.

The effects on total serum IgE of environmental tobacco smoke (ETS) exposure and close contact to cats and/or dogs were negligible in all groups.

\section{Discussion}

We analyzed 5,918 data for total IgE levels in a population of 4,353 schoolchildren in East Germany in three surveys performed at time intervals of 3 years. We found a linear trend towards lower total serum IgE levels over time, in particular for nonatopic children. Living in households of more than 4 people, history of helminth 
Table 2. Results of the generalized estimating equations with log-transformed total serum IgE as the independent variable and survey as an additional fixed effect

\begin{tabular}{|c|c|c|c|c|c|c|c|c|c|c|c|c|c|c|c|}
\hline \multirow[t]{2}{*}{ Variable } & \multicolumn{5}{|c|}{ All children $(n=5,918)$} & \multicolumn{5}{|c|}{ Atopic children $(\mathrm{n}=1,840)$} & \multicolumn{5}{|c|}{ Nonatopic children $(\mathrm{n}=4,078)$} \\
\hline & Est. & LCL & UCL & $\mathrm{p}$ & MR & Est. & LCL & UCL & $\mathrm{p}$ & MR & Est. & LCL & UCL & $\mathrm{p}$ & MR \\
\hline \multicolumn{16}{|l|}{ Intercept } \\
\hline Intercept & 3.871 & 3.69 & 4.05 & 0.000 & & 4.55 & 4.23 & 4.86 & 0.000 & & 3.72 & 3.52 & 3.92 & 0.000 & \\
\hline \multicolumn{16}{|l|}{ Survey } \\
\hline Survey 1 & ref. & & & & & ref. & & & & & ref. & & & & \\
\hline Survey 2 & -0.091 & -0.16 & -0.02 & 0.009 & 0.91 & 0.09 & -0.03 & 0.21 & 0.133 & 1.09 & -0.12 & -0.20 & -0.04 & 0.003 & 0.88 \\
\hline Survey 3 & -0.182 & -0.29 & -0.08 & 0.001 & 0.83 & 0.10 & -0.07 & 0.27 & 0.236 & 1.10 & -0.24 & -0.36 & -0.13 & 0.000 & 0.78 \\
\hline \multicolumn{16}{|l|}{ Gender } \\
\hline Male & ref. & & & & & ref. & & & & & ref. & & & & \\
\hline Female & 0.336 & 0.25 & 0.42 & 0.000 & 1.40 & 0.28 & 0.15 & 0.41 & 0.000 & 1.32 & 0.12 & 0.03 & 0.21 & 0.010 & 1.12 \\
\hline \multicolumn{16}{|l|}{ Age group } \\
\hline $5-7$ years & ref. & & & & & ref. & & & & & ref. & & & & \\
\hline $8-10$ years & 0.214 & 0.15 & 0.28 & 0.000 & 1.24 & 0.22 & 0.11 & 0.34 & 0.000 & 1.25 & 0.12 & 0.04 & 0.19 & 0.003 & 1.13 \\
\hline $11-14$ years & 0.220 & 0.12 & 0.32 & 0.000 & 1.25 & 0.22 & 0.06 & 0.37 & 0.006 & 1.24 & 0.05 & -0.05 & 0.16 & 0.322 & 1.06 \\
\hline \multicolumn{16}{|l|}{ Study location } \\
\hline Zerbst & ref. & & & & & ref. & & & & & ref. & & & & \\
\hline Bitterfeld & 0.084 & -0.02 & 0.19 & 0.107 & 1.09 & -0.12 & -0.28 & 0.05 & 0.158 & 0.89 & 0.10 & -0.01 & 0.20 & 0.081 & 1.10 \\
\hline Hettstedt & 0.019 & -0.09 & 0.13 & 0.729 & 1.02 & -0.22 & -0.39 & -0.05 & 0.010 & 0.80 & -0.06 & -0.17 & 0.06 & 0.334 & 0.94 \\
\hline \multicolumn{16}{|c|}{ Parental education } \\
\hline$<10$ years & ref. & & & & & ref. & & & & & ref. & & & & \\
\hline $10-12$ years & -0.151 & -0.30 & -0.00 & 0.045 & 0.86 & 0.17 & -0.08 & 0.42 & 0.176 & 1.19 & -0.20 & -0.36 & -0.04 & 0.016 & 0.82 \\
\hline$>12$ years & -0.164 & -0.31 & -0.01 & 0.033 & 0.85 & 0.16 & -0.09 & 0.40 & 0.223 & 1.17 & -0.27 & -0.43 & -0.10 & 0.002 & 0.77 \\
\hline \multicolumn{16}{|l|}{ Household size } \\
\hline$\leq 4$ persons & ref. & & & & & ref. & & & & & ref. & & & & \\
\hline$>4$ persons & 0.208 & 0.11 & 0.30 & 0.000 & 1.23 & 0.23 & 0.07 & 0.40 & 0.006 & 1.26 & 0.28 & 0.17 & 0.38 & 0.000 & 1.32 \\
\hline \multicolumn{16}{|c|}{ Helminth infection } \\
\hline & ref. & & & & & ref. & & & & & ref. & & & & \\
\hline Yes & 0.126 & 0.02 & 0.23 & 0.021 & 1.13 & 0.11 & -0.08 & 0.30 & 0.252 & 1.11 & 0.20 & 0.08 & 0.32 & 0.001 & 1.22 \\
\hline Unknown & 0.053 & -0.07 & 0.18 & 0.399 & 1.05 & 0.08 & -0.11 & 0.27 & 0.421 & 1.08 & 0.08 & -0.05 & 0.22 & 0.234 & 1.08 \\
\hline \multicolumn{16}{|c|}{ Parental allergy } \\
\hline No & ref. & & & & & ref. & & & & & ref. & & & & \\
\hline Yes & 0.107 & 0.03 & 0.18 & 0.005 & 1.11 & 0.05 & -0.07 & 0.17 & 0.455 & 1.05 & 0.02 & -0.06 & 0.10 & 0.579 & 1.02 \\
\hline \multicolumn{16}{|c|}{ Smoking at home } \\
\hline No & ref. & & & & & ref. & & & & & ref. & & & & \\
\hline Yes & 0.032 & -0.04 & 0.11 & 0.393 & 1.03 & -0.01 & -0.13 & 0.11 & 0.847 & 0.99 & 0.08 & -0.01 & 0.16 & 0.068 & 1.08 \\
\hline \multicolumn{16}{|c|}{ Contact to cats/dogs } \\
\hline No & ref. & & & & & ref. & & & & & ref. & & & & \\
\hline Yes & -0.017 & -0.08 & 0.05 & 0.616 & 0.98 & 0.02 & -0.09 & 0.12 & 0.724 & 1.02 & 0.04 & -0.03 & 0.12 & 0.261 & 1.04 \\
\hline
\end{tabular}


infestation, parental allergy and higher age of the children were associated with higher IgE levels. Higher parental education was associated with lower IgE values. Significantly higher total serum IgE levels were seen in boys as compared to girls. In the group of nonatopic children, there was no longer a gender effect.

Summarizing the potential influences of temporal changes in predictors of total IgE levels, we found only the decline of helminth infestations consistent with the decreasing trend for total IgE levels. Although several other potential risk factors for total IgE, such as parental atopy, crowding and contact to cats and dogs, tended to increase, the total IgE levels decreased over time.

Behrendt et al. [25] determined total serum IgE levels in children (mean age 6.4 years) from four towns in East Germany in 1991 and calculated a geometric mean of 51.4 $\mathrm{kU} / \mathrm{l}$. Using a similar method, we found slightly higher IgE levels (geometric mean: $66.3 \mathrm{kU} / \mathrm{l}$ in 1992-1993 and $57.9 \mathrm{kU} / \mathrm{l}$ in 1998-1999), which was partly due to the higher average age in our survey (geometric mean for the 6 -year-old children in our study was $52.2 \mathrm{kU} / \mathrm{l}$ ). In addition, our study covered a more rural area. IgE levels in a comparable group of children in West Germany were clearly lower (geometric mean $20.3 \mathrm{kU} / \mathrm{l}$ ) [25]. In contrast, the geometric mean of total IgE in a study of schoolchildren in rural Ecuador was as high as 1,004 kU/1 [26].

In line with our study findings, other studies have described higher values of total serum IgE for male children [27] and adults $[6,28]$ as compared to females. $\mathrm{Ku}$ lig et al. [1] found significantly higher values in boys, also in a group of nonatopic children. However, our data suggest that in our study population, the gender difference in the overall group is partly due to a higher prevalence of atopy among boys than girls (37.5 vs. $24.1 \%$ ) and higher total serum IgE levels in atopic boys compared to atopic girls, as in the stratified analysis, there was no gender effect in the group of nonatopic children. Similar sexspecific differences in prevalence rates of allergic sensitization assessed by skin prick tests have been described by Sherrill et al. [29], with $39.2 \%$ for boys and $26.4 \%$ for girls in a population of 6-year-old children in Tucson, Ariz., USA.

Worldwide, there is a striking pattern of allergic diseases with a strong gradient from developing and rural to industrialized and urban areas [30] with region-specific temporal changes [31, 32]. One obvious difference in living conditions between developing and industrialized regions besides socioeconomic status consists of lower hygienic standards and greater exposure to parasitic and other infections in developing areas. The 'hygiene hy- pothesis' [33] claims that the maturing immune system of children in westernized wealthy regions is less challenged by infectious diseases and is therefore more likely to develop an imbalance between the Th1/Th2 immune responses. This results in a tendency to target Th2-dependent reactions on ubiquitous harmless antigens, as observed in atopic individuals [33]. This hypothesis has been taken further by many researchers to develop a model claiming that early chronic or long-lasting parasitic infections lead to the activation of a regulatory network of the immune system that has anti-inflammatory effects on Th1 as well as Th2 responses [34].

A higher prevalence of helminth infestation has been suggested as one explanation for higher IgE levels but a lower prevalence of allergic diseases in East Germany. In our study, $14.9 \%$ of the girls and $11.7 \%$ of the boys reported a history of helminth infestation, which is higher than comparable data from West Germany, such as the $5 \%$ lifetime prevalence reported by Behrendt et al. [25]. Our study showed that children with a history of helminth infestation have higher IgE. In the nonatopic group, that effect was even stronger. During the observation period of the study, IgE levels as well as the lifetime prevalence of helminth infestation decreased, and average age at the time of the first helminth infection rose from 4.2 years in the second survey to 5.0 years in the third survey. The decline in helminth infestation is consistent with the observed decreasing levels of total IgE during the 1990s. However, adjustments for helminth infestation did not completely explain the declining total IgE levels. The reasons for the modest effect of helminth infestation might have been underreporting on the questionnaire because it was too long ago or parents did not recognize it. Also, an infestation from several years previously may have lost its impact on IgE levels.

Strachan [33] found that hay fever was inversely related to the number of children in the household at age 11 and suggested that with an increasing number of people per household, infection rates in childhood also rise due to frequent contact with pathogens and chains of reinfection. It has also been reported that total serum IgE levels increase with the number of people per dwelling [2]. Our analysis further supports this hypothesis. Interestingly, Behrendt et al. [25] only found a significant effect of household size on IgE in East German and not in West German children. In our study, the effect of household size of more than 4 people on IgE decreased between 1993 and 1999. This trend may be another manifestation of a converging tendency of lifestyle factors between East and West. 
Although an enhancing effect on IgE production has been reported for cigarette smoking $[6,35]$, the impact of ETS on serum IgE levels is controversial $[36,37]$. In this study, there was no association between ETS and IgE.

In our study, the percentage of children having close contact to cats or dogs increased clearly between 1993 and 1999 from 46.6 to $61.4 \%$ but its impact on IgE was not significant and was close to nil in all three groups.

One of the strengths of the present study is that identical methods, including an identical questionnaire, were used in all three surveys. This study used a large data set of total IgE measurements, with intra- and interassay coefficients of variation being $7 \%$. However, there are also limitations of the study that should be addressed.

A possible limitation lies in the lower participation rates in the second and third surveys, although they did not lead to a selection bias regarding parental education. The survey question regarding whether the child had ever had a helminth infection and if so at what age was not present in the first survey. Therefore, this information was extrapolated for the cohort that answered the question in the second survey. Retrospective assessment of the childrens' age at first helminth infestation by parents might have led to misclassification of children in the first survey.

Overall, IgE levels decreased over time in our study population, while the prevalence of strong sensitization (at least one specific $\operatorname{IgE} \geq 17.5 \mathrm{kU} / \mathrm{l}$ ) and allergic diseases (except for hay fever) increased [18]. In part this could be understood as a loss of parasite-induced immunomodulatory counterregulation due to decreasing helminth infestation. Schäfer et al. [17] proved a negative association between helminth infestation and subsequent allergic sensitization in our study population.

Nickel et al. [27] have shown that IgE values of children aged 5 years and older correlate well with IgE levels later in life, while in earlier childhood, IgE levels vary considerably and are not predictive for the future development of IgE. In our study, the intraindividual correlation for IgE levels was also high ( 0.84 between surveys 1 and 2, 0.83 between surveys 2 and 3 , and 0.72 between surveys 1 and 3). Therefore, the results of this study based on a population of school-aged children (5-13 years) are likely to be predictive for the future development of IgE levels in these individuals.

\section{Acknowledgments}

We wish to thank all the children and parents for their participation in this study. The fieldwork undertaken for this study was supported by a governmental funding source, the Federal Environment Agency(Umweltbundesamt; Grant No. FKZ29861724).

\section{References}

1 Kulig M, Tacke U, Forster J, Edenharter G, Bergmann R, Lau S, Wahn V, Zepp F, Wahn U: Serum IgE levels during the first 6 years of life. J Pediatr 1999;134:453-458.

2 Wjst M, Heinrich J, Liu P, Dold S, Wassmer G, Merkel G, Huelsse C, Wichmann HE: Indoor factors and IgE levels in children. Allergy 1994;49:766-771.

3 Graves PE, Kabesch M, Halonen M, Holberg CJ, Baldini M, Fritzsch C, Weiland SK, Erickson RP, von Mutius E, Martinez FD: A cluster of seven tightly linked polymorphisms in the IL-13 gene is associated with total serum IgE levels in three populations of white children. J Allergy Clin Immunol 2000;105:506-513.

4 Weidinger S, Gieger C, Rodriguez E, Baurecht $\mathrm{H}$, Mempel M, Klopp N, Gohlke H, Wagenpfeil S, Ollert $\mathrm{M}$, Ring J, Behrendt $\mathrm{H}$, Heinrich J, Novak N, Bieber T, Kramer U, Berdel D, von Berg A, Bauer CP, Herbarth O, Koletzko S, Prokisch H, Mehta D, Meitinger T, Depner M, von Mutius E, Liang L, Moffatt M, Cookson W, Kabesch M, Wichmann HE, Illig T: Genome-wide scan on total serum IgE levels identifies FCER1A as novel susceptibility locus. PLoS Genet 2008;4:e1000166.
5 Perkin MR, Strachan DP: Which aspects of the farming lifestyle explain the inverse association with childhood allergy? J Allergy Clin Immunol 2006;117:1374-1381.

6 Criqui MH, Seibles JA, Hamburger RN, Coughlin SS, Gabriel S: Epidemiology of immunoglobulin E levels in a defined population. Ann Allergy 1990;64:308-313.

7 Chen CM, Sausenthaler S, Bischof W, Herbarth $\mathrm{O}$, Borte $\mathrm{M}$, Behrendt $\mathrm{H}$, Kramer U, Williams HC, Wichmann HE, Heinrich J: Perinatal exposure to endotoxin and the development of eczema during the first 6 years of life. Clin Exp Dermatol 2010;35:238-244.

8 Sengler C, Lau S, Wahn U, Nickel R: Interactions between genes and environmental factors in asthma and atopy: new developments. Respir Res 2002;3:7.

$9 \mathrm{Xu}$ J, Postma DS, Howard TD, Koppelman GH, Zheng SL, Stine OC, Bleecker ER, Meyers DA: Major genes regulating total serum immunoglobulin E levels in families with asthma. Am J Hum Genet 2000;67:11631173.
10 Maziak W: The asthma epidemic and our artificial habitats. BMC Pulm Med 2005;5:5.

11 Heinrich J, Nowak D, Wassmer G, Jorres R, Wjst M, Berger J, Magnussen $\mathrm{H}$, Wichmann HE: Age-dependent differences in the prevalence of allergic rhinitis and atopic sensitization between an Eastern and a Western German city. Allergy 1998;53:89-93.

12 Krämer U, Oppermann H, Ranft U, Schäfer T, Ring J, Behrendt H: Differences in allergy trends between East and West Germany and possible explanations. Clin Exp Allergy 2010;40:289-298.

13 von Mutius E, Fritzsch C, Weiland SK, Roll G, Magnussen H: Prevalence of asthma and allergic disorders among children in united Germany: a descriptive comparison. BMJ 1992;305:1395-1399.

14 von Mutius E, Illi S, Nicolai T, Martinez FD: Relation of indoor heating with asthma, allergic sensitisation, and bronchial responsiveness: survey of children in south Bavaria. BMJ 1996;312:1448-1450.

15 Winkler G, Brasche S, Heinrich J: Trends in food intake in adults from the city of Erfurt before and after the German reunification. Ann Nutr Metab 1997;41:283-290. 
16 Dold S, Heinrich J, Wichmann HE, Wjst M: Ascaris-specific IgE and allergic sensitization in a cohort of school children in the former East Germany. J Allergy Clin Immunol 1998;102:414-420.

17 Schäfer T, Meyer T, Ring J, Wichmann HE, Heinrich J: Helminth infestation and the negative association with eczema (atopic/ nonatopic) and allergic sensitization. Allergy 2005;60:1014-1020.

18 Heinrich J, Hoelscher B, Frye C, Meyer I, Wjst M, Wichmann HE: Trends in prevalence of atopic diseases and allergic sensitization in children in Eastern Germany. Eur Respir J 2002;19:1040-1046.

19 von Mutius E, Weiland SK, Fritzsch C, Duhme H, Keil U: Increasing prevalence of hay fever and atopy among children in Leipzig, East Germany. Lancet 1998;351: 862-866.

20 Krämer U, Link E, Oppermann H, Ranft U, Schafer T, Thriene B, Behrendt H, Ring J: Studying school beginners in western and eastern Germany: allergy trends and sensitisations 1991-2000 (in German). Gesundheitswesen 2002;64:657-663.

21 Bergmann RL, Bergmann KE, LauSchadensdorf S, Luck W, Dannemann A, Bauer CP, Dorsch W, Forster J, Schmidt E, Schulz J, et al: Atopic diseases in infancy. The German multicenter atopy study (MAS-90). Pediatr Allergy Immunol 1994;5(6 suppl): 19-25.

22 Heinrich J, Hoelscher B, Frye C, Meyer I, Pitz M, Cyrys J, Wjst M, Neas L, Wichmann HE: Improved air quality in reunified Germany and decreases in respiratory symptoms. Epidemiology 2002;13:394-401.
23 Heinrich J, Hoelscher B, Wjst M, Ritz B, Cyrys J, Wichmann H: Respiratory diseases and allergies in two polluted areas in East Germany. Environ Health Perspect 1999; 107:53-62.

24 Asher MI, Keil U, Anderson HR, Beasley R, Crane J, Martinez F, Mitchell EA, Pearce N, Sibbald B, Stewart AW, et al: International Study of Asthma and Allergies in Childhood (ISAAC): rationale and methods. Eur Respir J 1995;8:483-491.

25 Behrendt H, Krämer U, Dolgner R, Hinrichs J, Willer H, Hagenbeck H: Elevated levels of total serum IgE in East German children: atopy, parasites or pollutants? Allergo J 1993;2: $31-40$

26 Cooper PJ, Alexander N, Moncayo AL, Benitez SM, Chico ME, Vaca MG, Griffin GE: Environmental determinants of total IgE among school children living in the rural tropics: importance of geohelminth infections and effect of anthelmintic treatment. BMC Immunol 2008;9:33.

27 Nickel R, Illi S, Lau S, Sommerfeld C, Bergmann R, Kamin W, Forster J, Schuster A, Niggemann B, Wahn U: Variability of total serum immunoglobulin $\mathrm{E}$ levels from birth to the age of 10 years. A prospective evaluation in a large birth cohort (German Multicenter Allergy Study). Clin Exp Allergy 2005;35:619-623.

28 Grigoreas C, Pappas D, Galatas ID, Kollias G, Papadimos S, Papadakis P: Serum total IgE levels in a representative sample of a Greek population. I. Correlation with age, sex, and skin reactivity to common aeroallergens. $\mathrm{Al}-$ lergy 1993;48:142-146.

29 Sherrill DL, Stein R, Halonen M, Holberg CJ, Wright A, Martinez FD: Total serum IgE and its association with asthma symptoms and allergic sensitization among children. J Allergy Clin Immunol 1999;104:28-36.
30 Worldwide variation in prevalence of symptoms of asthma, allergic rhinoconjunctivitis, and atopic eczema: ISAAC. The International Study of Asthma and Allergies in Childhood (ISAAC) Steering Committee. Lancet 1998;351:1225-1232.

31 Asher MI, Montefort S, Bjorksten B, Lai CK, Strachan DP, Weiland SK, Williams H; ISAAC Phase Three Study Group: Worldwide time trends in the prevalence of symptoms of asthma, allergic rhinoconjunctivitis, and eczema in childhood: ISAAC Phases One and Three repeat multicountry crosssectional surveys. Lancet 2006;368:733-743.

32 Zöllner IK, Weiland SK, Piechotowski I, Gabrio T, von Mutius E, Link B, Pfaff G, Kouros $B$, Wuthe J: No increase in the prevalence of asthma, allergies, and atopic sensitisation among children in Germany: 1992-2001. Thorax 2005;60:545-548.

33 Strachan DP: Hay fever, hygiene, and household size. BMJ 1989;299:1259-1260.

34 Yazdanbakhsh M, Kremsner PG, van Ree R: Allergy, parasites, and the hygiene hypothesis. Science 2002;296:490-494

35 Miyake Y, Miyamoto S, Ohya Y, Sasaki S, Matsunaga I, Yoshida T, Hirota Y, Oda H: Relationship between active and passive smoking and total serum IgE levels in Japanese women: baseline data from the Osaka Maternal and Child Health Study. Int Arch Allergy Immunol 2004;135:221-228.

36 Kjellman NI: Effect of parental smoking on IgE levels in children. Lancet 1981;1:993994

37 Ownby DR, McCullough J: Passive exposure to cigarette smoke does not increase allergic sensitization in children. J Allergy Clin Immunol 1988;82:634-638. 